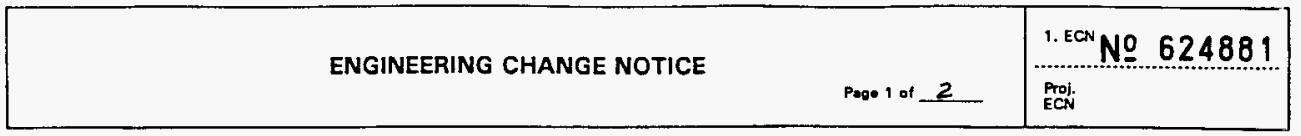

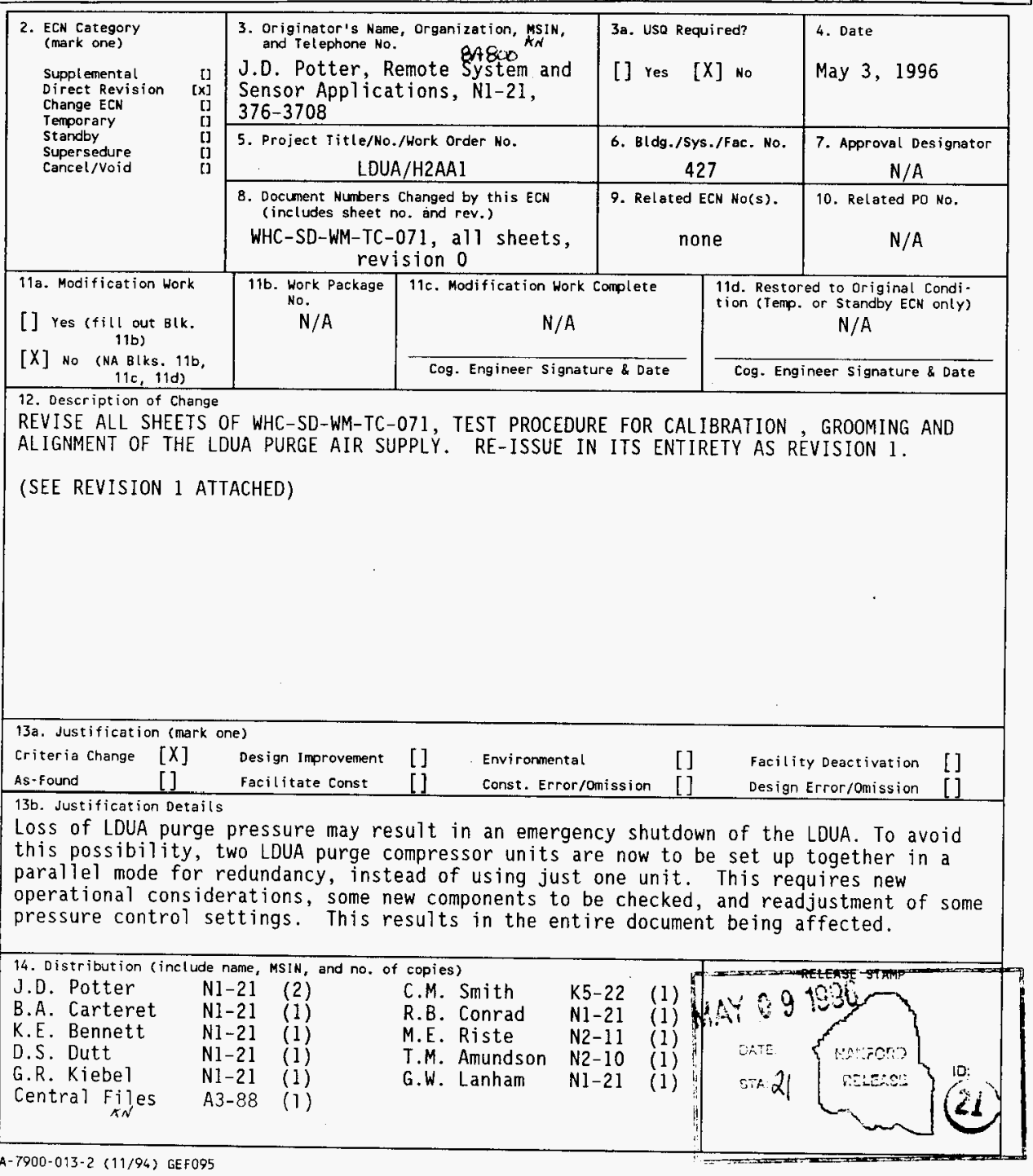




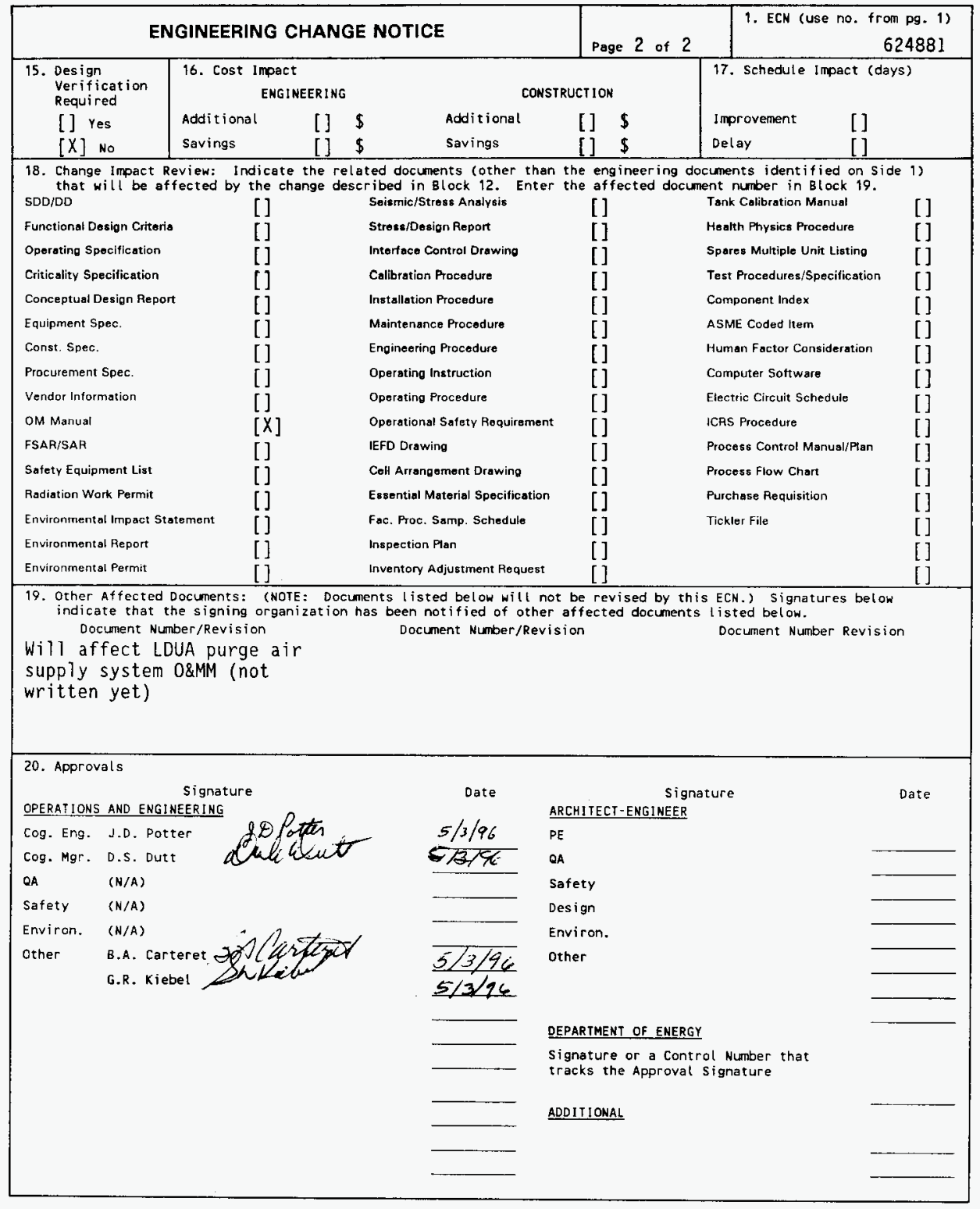




\section{Test Procedure for Calibration, Grooming and Alignment of the LDUA Purge Air Supply (LDUA System 5230)}

\section{J.D. Potter}

Westinghouse Hanford Company, Richland, WA 99352

U.S. Department of Energy Contract DE-AC06-87RL10930

ECN 624881

EDT/ECN: EQF-ZT2365 KN UC: 2060

Org Code: 8A800 Charge Code: H1EO2

B\&R Code: EW4010000 Total Pages: 23 kN

Key Words: LDUA, PASS, Purge, CG\&A, Test, Procedure, compressor, Calibration

Abstract: The Light Duty Utility Arm (LDUA) is a remotely operated manipulator used to enter into underground waste tanks through one of the tank risers. National Electric Code requirements mandate that the in-tank portions of the LDUA be maintained at a positive pressure for entrance into a flammable atmosphere. The LDUA Purge Air Supply system (PASS) uses small portable air compressors to provide a constant low flow of instrument grade air for this purpose. This document is used to assure that the instrumentation and equipment comprising the PASS are properly adjusted in order that the PASS can successfully achieve its intended functions.

TRADEMARK DISCLAIMER. Reference herein to any specific commercial product, process, or service by trade name, trademark, manufacturer, or otherwise, does not necessarily constitute or imply its endorsement, recommendation, or favoring by the United States Government or any agency thereof or its contractors or subcontractors.

Printed in the United States of America. To obtain copies of this document, contact: WHC/BCS Document Control Services, P.O. Box 1970, Mailstop H6-08, Richland WA 99352, Phone (509) 372-2420; Fax (509) 376.4989 .
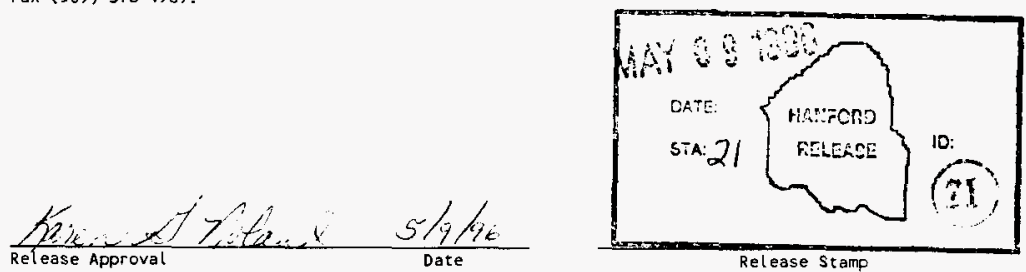

\section{Approved for Public Release}


(2) Title

Test Procedure for Calibration, Grooming and Alignment of the LDUA Purge Air Supply (LDUA System 5230)

CHANGE CONTROL RECORD

\begin{tabular}{|c|l|}
\hline (3) Revision & (4) Description of Change - Replace, Add, and Delete Pages \\
\hline rev. 0 & (7) $\begin{array}{l}\text { This document was initially issued as } \\
\text { revision } 0, \text { approved on } 12 / 13 / 95 \mathrm{per} \\
\text { EDT } 612362\end{array}$ \\
\hline
\end{tabular}

rev. 1 All pages of the document were changed and RS the document re-issued as revision 1 , as a direct change per ECN 624881 .

\begin{tabular}{|c|c|}
\hline \multicolumn{2}{|c|}{ Authorized for Release } \\
\hline (5) Cog. Engr & (6) Cog. Mgr. Date \\
\hline $\begin{array}{l}\text { dD Potter } \\
5 / 8 / 96\end{array}$ & \\
\hline
\end{tabular}

\begin{tabular}{|l|l|}
\hline & \\
\hline & \\
\hline &
\end{tabular}


WHC-SD-WM-TC-071

Revision 1

\section{TEST PROCEDURE \\ for \\ CALIBRATION, GROONING AND ALIGNMENT \\ OF THE LDUA Purge Air Supply \\ (LDUA System 5230)}

May 3, 1996

by

J.D. POTTER

Remote System and Sensor Applications

Westinghouse Hanford Company

Richland, Washington 


\section{TABLE OF CONTENTS}

Test Procedure for

Calibration, Grooming and Alignment

of the LDUA Purge Air Supply

Page Number

1.0 TEST ITEM IDENTIFICATION . . . . . . . . . . . . . . . . . . 1

2.0 GENERAL DESCRIPTION . . . . . . . . . . . . . . . . 2

3.0 TEST CONDITION LIMITS . . . . . . . . . . . . . . . . 3

4.0 INSTRUMENTS AND CALIBRATION . . . . . . . . . . . . . . . . 3

5.0 FACILITIES, EQUIPMENT, AND MATERIALS . . . . . . . . . . . . 4

6.0 SAFETY ............................ . . . 4

7.0 MAINTENANCE AND FAILURES . . . . . . . . . . . . . . . . . . 5

B.0 TEST DATA . . . . . . . . . . . . . . . . . . . 5

9.0 PERSONNEL REQUIREMENTS ......................... . . . 5

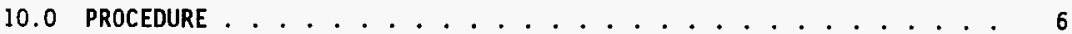

10.1 RELIEF VALVE TEST . . . . . . . . . . . . . . . 6

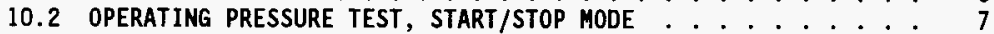

10.3 OPERATING PRESSURE TEST, CONTINUOUS RUN MODE . . . . . . . . . 8

10.4 PURGE AIR DELIVERY PRESSURE .................... . . . . . 9

10.4.1 Adjust Purge Delivery Pressure . . . . . . . . . . . . . . 9

10.4.2 Purge Air Relief Valve Test........... 10

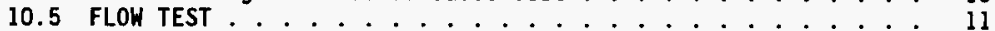

10.6 CHECK VALVE TEST

10.7 HEAT STRIP THERMOSTAT TEST . . . . . . . . . . . . . . . . 13

10.8 DUAL OPERATION TEST . . . . . . . . . . . . . . . . . . 14

10.9 POST-TEST OPERATIONS . . . . . . . . . . . . . . . . . 16

11.0 DISPOSITION OF TEST ITEMS . . . . . . . . . . . . . . . . 16

12.0 DATA SHEETS . . . . . . . . . . . . . . . . . 16

FIGURES

Figure 1, Mechanical Schematic ................... 19

Figure 2, Electrical Schematic . . . . . . . . . . . . . . 20 
WHC-SD-WM-TC-071

Revision 1

Test Procedure for

Calibration, Grooming and Alignment

of the LDUA Purge Air Supply

\subsection{TEST ITEM IDENTIFICATION}

The LDUA Purge Air Supply System (PASS) provides a constant low flow of instrument grade (clean, low moisture) air to enable the in-tank portions of the LDUA to comply with National Electric Code requirements for operation in Class 1, Division 1, Group B flammable atmospheres by maintaining the internal pressure of the end effector, LDUA, and VPM above the pressure of the external atmosphere. This pressure differential al so keeps the interior surfaces of these components from becoming contaminated in the event of seal leakage. In addition, the PASS will provide limited compressed air at the LDUA Tool Interface Plate (TIP) for use by some end effectors requiring low demand pneumatics. Excessively low purge pressure may result in emergency shutdown of the LDUA, with arm becoming $7 \mathrm{imp}$. The PASS is a separate stand-alone subsystem of the LDUA. Sensors, alarms, and controls responding to low LDUA purge pressure, are part of the LDUA I\&C and are not included in the PASS.

The PASS utilizes two identical compressor units, each of which is designed for outdoor use and has wheels and a handle for easy portability. See figure 1, for a schematic showing the mechanical relationship of the components comprising a PASS compressor unit, with an electrical schematic as shown in figure 2. Each compressor unit features a 20 gallon ASME coded receiver with a continuous duty oil-less compressor which supplies air at 85 to $135 \mathrm{psig}$. A pressure regulator at the end of the hose will deliver at least 3.5 SCFM purge air to the LDUA at a pressure of 75 to 80 psig. Each compressor unit has a filter to remove particles of 0.5 micron or larger and an air drier to assure that the air will not condense at LDUA operating temperatures of $-20^{\circ} \mathrm{F}$. Pressure differentials across The filters can be locally monitored, as can the air delivery pressure. A 50 foot long power cord is used to furnish electrical power of $115 \mathrm{vac}, 60 \mathrm{~Hz}, 22$ amp to the compressor motor. A 25 foot long air hose is used for attachment to the purge inlet of the LDUA using color coded, keyed quick connects to assure proper connections. Each compressor has the capability to be operated either in a "continuous run" mode or a "start/stop" mode, as determined by the position of hand valve (HV-l). To select the "continuous run" mode the operator closes hand valve (HV-l) to isolate pressure switch (PS-I), thereby allowing an unloader valve (PR-1) to control the output pressure between 100 to $135 \mathrm{psig}$. When the hand valve (HV-1) is open, the pressure switch will control the output pressure between 85 to 120 psig. Only the "continuous run" mode will be utilized for normal LDUA operations.

Each of the two PASS compressor units was designed and fabricated in accordance with PR 414302, by Portland Compressor, Portland, Oregon (503) 2350200. For parts list and equipment arrangement of the PASS see drawing H-6-14099, LDUA Purge Air Suppiy. In the as-received condition there were no unique vendor serial numbers assigned to these units to differentiate between them. Unique serial numbers will be assigned by this procedure, and an identification $p$ late added to each unit to permit differentiation between compressor units. 
WHC-SD-WM-TC-071

Revision 1

\subsection{GENERAL DESCRIPTION}

The ability of the PASS to supply purge air to the LDUA at the required pressure and flow rate is essential for assurance that the sensors of the LDUA do not initiate emergency shutdown of the LDUA because of low purge pressure. Therefore the objective of this test is to test each PASS to verify that it does deliver adequate flow at the proper pressures (see section 3.0, below) at its point of interface with the LDUA, and that system pressure control and pressure relief valves function as designed. The filter and dryer supplied with the units are standard commercial components and will not be tested for verification of air supply quality (i.e. particulate and dew point).

In general, the testing to be performed on the two PASS compressor units will consist of six portions as outlined below:

1) Removal of pressure relief valve (RV-1), verification of its proper relief pressure followed by its re-installation.

2) Individual operation of each unit in both the "continuous run" mode and the "start/stop" mode and setting the upper and lower boundaries of the pressure in the air receiver tank.

3) Measurement of the pressure and flow at the end of the air hose at required delivery pressure.

4) Removal of check valves ( $C V-2)$ and (CV-3), performance of reverse pressure leak check followed by their re-installation.

5) Chilling down the heat strip thermostat with ice and verifying operation of heat strip.

6) System operation verification by attaching the outlet of each compressor unit to a common hose and operating in a manner as in the field. 


\subsection{TEST CONDITION LIMITS}

The parameters, and their allowable limits, applicable to this procedure are 1 isted below:

- Tank relief valve setting

- Continuous run mode pressure

- Start/stop mode pressure

- Purge delivery pressure

- Purge relief valve setting

- Flow rate

- Thermostat setting
Relief valve (RV-1) shall crack (begin opening) at 140 to 144 psig.

In the continuous run mode the unloader valve shall control the pressure in the receiver to be between 100 to $135 \mathrm{psig}$.

In the start/stop mode the pressure switch shall control the pressure in the receiver to be between 85 to 120 psig.

The regulator $(P C-1)$ shall control the pressure at the end of the purge supply hose to be 75 to $80 \mathrm{psig}$.

The regulator unit includes a relief valve (PR-2) which shall limit the pressure at the end of the purge supply hose to less than 100 psig.

The flow rate at the end of the purge supply hose shall be at least 3.5 SCFM at a pressure of 75 to 80 psig.

The heat strip thermostat shall turn on the heat strip at temperature of $32{ }^{\circ} \mathrm{F}$ or higher.

\subsection{INSTRUMENTS AND CALIBRATION}

The instruments listed below are to be in proper calibration for their usage in this test. valid calibration data supplied by either WHC Calibration Services or the manufacturer of the instrument is acceptable.

- Flowmeter

- Pressure gage
The flowmeter shall be capable of measuring air flow rates from 1.0 to 6.0 SCFM at pressures between 70 to $135 \mathrm{psig}$, with an accuracy of $\pm 10 \%$ or better.

Pressure gage with range of 0 to $200 \mathrm{psig}$, with an accuracy of $0.5 \%$ or better. 


\subsection{FACILITIES, EQUIPMENT, AND MATERIALS}

Testing will be conducted on the mezzanine (cranebay room 500) at the 42'-6" elevation of building 427 (FMEF). The following facilities and equipment will be required for the performance of the test:

- Electrical power

- Flowmeter

- Pressure gages

- Ice Pack

- Hand valve

- Miscellaneous

\author{
$120 \mathrm{vac} / 60 \mathrm{~Hz}$, single-phase, $30 \mathrm{amp}$ \\ (see section 4.0 ) \\ (see section 4.0 ) \\ common household type ice pack \\ $1 / 2$ " hand valve, rated for 150 psig operating \\ pressure, or greater \\ hand tools, duct tape, $1 / 2$ inch pipe fittings, \\ pipe thread sealant tape
}

\subsection{SAFETY}

The following safety considerations, warnings and cautions pertaining to personnel hazards and equipment damage should be observed and adhered to during the performance of this testing:

- Equipment shall be operated in accordance with WHC-CM-1-10, Safety Manua 7.

- The electrical power cord shall be unplugged from its socket whenever doing maintenance or other servicing of the PASS or test equipment for which the compressor is not required to be running.

- The free end of the purge supply hose shall be tethered to a rigid support before initiating air flow through it.

- Before breaking any pipe or tube fittings all pressure must be verified removed from the receiver and plumbing by opening the bleed valve (TV-2) at the end of the hose, opening hand valve (HV-2), and observing no pressure remaining on receiver gage (PI-1).

- Before beginning a task, the Cognizant Test Engineer (CTE) is responsible to assure that all personnel taking part in the test have been briefed for their tasks and that they understand the procedure section being performed and any hazards associated with the task. 
WHC-SD-WM-TC-071

Revision 1

\subsection{MAINTENANCE AND FAILURES}

The CTE shall maintain a log book to document daily test activities, a 11 test anomalies, test deviations, and equipment failures. Care shall be taken to assure that reference is made to the unique serial number of each respective PASS compressor unit when making entries. The log book shall include the immediate resolution of anomalies and equipment failure, and the proposed long term resolution (if different than the immediate resolution). The CTE shall sign and date each entry made in the log book.

There are no components within the PASS which should require maintenance during the period of test performance. Any PASS component which fails and must be removed or replaced shall be subject to a repeat of those portions of this procedure to which the component has been previously subjected to.

\subsection{TEST DATA}

Acceptable test completion is indicated by the signature of the CTE at the end of each respective section. A separate copy of the procedure, with data sheets, will be maintained for each of the PASS units. Data will be recorded on the data sheets provided in section 12.0 and will reference the serial number of the PASS unit tested. The person entering the data in the data sheets shall sign and date at the time entry is made.

\subsection{PERSONNEL REQUIREMENTS}

No special training, beyond that normally provided to WHC technicians, is required to perform these tests. The testing and work performed per this procedure will be accomplished by Engineers and technicians of WHC Remote System and Sensor Applications, under direction of the WHC Cognizant Test Engineer (CTE). One engineer and one technician will be required. Those persons designated as CTE's for this task are: J.D. Potter, C.M. Smith and K.E. Bennett. 


\section{WHC-SD-WM-TC-071 \\ Revision 1}

\subsection{PROCEDURE}

In general, the sequence of testing will be performed in the order in which it is presented in this section of the procedure. However, the CTE may authorize deviation from this test sequence at his discretion, providing he signs in the appropriate space indicated at the beginning of the test section to be performed. The CTE may also eliminate or add other steps to the test procedure at his discretion, providing they are of a non-hazardous nature. Such deviation from the procedure must be clearly red-lined into the procedure at the place where the change is to occur, and signed and dated by the CTE prior to its implementation.

Color videos and color stills may be made of each test setup at the CTES discretion.

NOTE: While operating the PASS do not manually turn off the compressor at the main switch while the motor is running. Return to the start/stop mode if necessary and allow the pressure switch to turn the unit off before turning main switch off. Failing to do so will not allow the pressure release valve $(S V-1)$ to vent pressure from cylinder head, resulting in possible failure of compressor to restart. It may then be necessary to vent receiver tank to ambient before attempting restart.

NOTE: Before starting this test procedure, each PASS unit should be verified to be permanently marked with the following information as a minimum:

\section{H-6-14099-1 LDUA Purge Air Supply \\ LDUA System Number 5230 \\ Serial Number $X X X$}

where $X X X$ is a unique three digit number assigned by the CTE, the first number being 001 , then 002, 003, etc.

\subsection{RELIEF VALVE TEST}

This section of the procedure is performed to assure that the receiver tank pressure relief valve (RV-1) on each of the two PASS compressor units will provide its function as a backup safety device to protect against overpressurization of the air receiver tank. This section of the procedure must be successfully completed before operating the compressor.

1) Remove pressure relief valve (RV-1) from the compressor unit.

2) Send the relief valve to the WHC Calibration Services (372-0072) to verify/adjust its cracking pressure to be between 140 to $144 \mathrm{psig.}$ Record its final cracking pressure in the appropriate block provided in the data sheet.

3) Reinstall the relief valve.

Above section completed:

$$
\text { (signature of CTE) }
$$




\subsection{OPERATING PRESSURE TEST, START/STOP MODE}

This section of the procedure is performed to verify/adjust the Pressure Switch (PS-1) of each PASS compressor unit as required to maintain the air receiver pressure within proper limits when the compressor unit is operating in the Start/Stop mode.

1) Verify/attach the air hose to the outlet of the compressor unit (use quick connects already installed on hose and compressor unit).

2) Remove the quick connect and pressure regulator unit $(P C-1)$ from the free end of the hose and attach a 0 to 200 psig test gage on the end of the hose. Install an air bleed valve for bleeding off system pressure when required. Tether the end of the hose to a rigid structure for flow.

3) Open hand valves (HV-1) and (HV-2). NOTE: Opening hand valve (HV-1) will place the PASS in the start/stop mode of operation.

4) Turn on the air compressor and observe pressure gage (PI-1) and the test gage when the pressure switch (PS-1) actuates, stopping the compressor motor.

5) The receiver tank pressure will slowly decay due to bleed air flow from the membrane dryer (or by cracking the bleed valve). Observe pressure gage (PI-1) and the test gage when the pressure switch (PS-1) actuates, starting the compressor motor. The pressure switch should actuate at 85 to $90 \mathrm{psig}$, as indicated on the test gage. If the pressure switch does not actuate within these 1 imits it shall be re-adjusted per manufacturers instructions to be within Timits.

6) The receiver tank pressure will slowly increase until the pressure. switch (PS-1) again actuates, stopping the compressor motor. Observe pressure gage (PI-1) and the test gage when the pressure switch (PS-1) actuates. The pressure switch should actuate at no more than $120 \mathrm{psig}$, as indicated on the test gage. If the pressure switch does not actuate before this pressure is reached, it is defective and should be replaced.

7) Allow the compressor to cycle three additional times, and observe both gages to determine the pressures at which the compressor starts and stops. Enter the readings of both pressure gages, at which the compressor starts and stops, in the block provided on the data sheet.

8) Turn off the compressor and bleed off air receiver pressure to zero, by opening the bleed valve.

9) Close hand valve (HV-2) and the bleed valve. Remove the bleed valve, the pressure gage, and the tee fitting from the end of the hose unless required for other tests.

Above section completed:

$$
\text { (signature of (TE) }
$$


WHC-SD-WM-TC-071

Revision 1

\subsection{OPERATING PRESSURE TEST, CONTINUOUS RUN MODE}

This section of the procedure is performed to verify/adjust the unloader valve (PR-1) of each PASS compressor unit as required to maintain the air receiver pressure within proper limits when the compressor unit is operating in the Continuous Run mode. Section 10.2 of the procedure should be completed before performing this section.

1) Verify/attach the air hose to the outlet of the compressor unit (use quick connects already installed on hose and compressor unit).

2) Remove the quick connect and regulator unit (PC-1) from the free end of the hose and attach a 0 to 200 psig test gage on the end of the hose. Install an air bleed valve for bleeding off system pressure when required. Tether the end of the hose to a rigid structure for flow.

3) Close hand valve (HV-1) and open hand valve (HV-2). NOTE: closing hand valve (HV-l) will place the PASS in the continuous run mode of operation.

4) Turn on the air compressor and observe pressure gage (PI-1) and the test gage when the unloader (PR-1) actuates, stopping the pressure buildup.

5) The receiver tank pressure will slowly decay due to bleed air flow from the membrane dryer (or by cracking the bleed valve). Observe pressure gage $(P I-1)$ and the test gage when the unloader valve (PR-1) actuates, beginning the pressure buildup. The unloader valve should actuate at between 100 to $105 \mathrm{psig}$, as indicated on the test gage. If the unloader does not actuate within these limits it shall be re-adjusted per manufacturers instructions to be within limits.

6) The receiver tank pressure will slowly increase until the unloader valve (PR-1) again actuates, venting and stopping the pressure increase. observe pressure gage (PI-1) and the test gage when the unloader valve actuates. The unloader valve should actuate at between 10 to $15 \mathrm{psig}$ higher than the pressure switch dropout setting observed in step 10.2.6, as indicated on the test gage. If the unloader does not actuate within these limits it shall be readjusted per manufacturers instructions to be within these 1 imits, and steps 5 and 6 repeated.

7) Allow the compressor to cycle three additional times, and observe both gages to determine the pressures at which the unloader valve actuates to start and stop pressure buildup. Enter the readings of both pressure gages at which the unloader valve actuates, in the block provided on the data sheet.

8) Turn off the compressor and bleed off air receiver pressure to zero, by opening the bleed valve. 
9) Close hand valve (HV-2) and the bleed valve. Reinstall the regulator unit $(P C-1)$ to the end of the purge supply hose.

Above section completed:

(signature of CTE)

(date)

\subsection{PURGE AIR DELIVERY PRESSURE}

This section of the procedure adjusts the regulator unit (PC-1) of each compressor unit and assures that the purge air delivered to the LDUA will remain within allowable limits. The bleed valve, test pressure gage, and the tee fitting should still be at end of hose as per section 10.3 .

\subsubsection{Adjust Purge Delivery Pressure}

1) Verify/close the bleed valve. Close hand valve (HV-1) and open hand valve (HV-2). NOTE: closing hand valve (HV-1) will place the compressor unit in the continuous run mode of operation.

2) Turn on the air compressor and allow pressure to build up until unloader valve stops pressure buildup.

3) Adjust the regulator unit (PC-1) until pressure on the test pressure gage stabilizes between 75 to $80 \mathrm{psig.} \mathrm{Record} \mathrm{pressures}$ observed on the test pressure gage and on the regulator pressure gage (PI-3) in the appropriate spaces of the data sheet.

4) Slightly crack the bleed valve to allow some flow. Allow the unloader valve (PR-1) to automatically go through its load/unload cycle at least three times. Verify that the pressure on the test gage remains between 75 to 80 psig.

5) Open hand valve (HV-1) to place the compressor unit in the "start/stop" mode of operation. Allow the pressure switch (PS-1) to automatically go through at least three start/stop cycles. Verify that the pressure on the test gage remains between 75 to 80 psig.

5) Turn off the compressor, vent all pressure to ambient.

Above section completed:

$$
\text { (signature of } \overline{C T E} \text { ) }
$$




\subsubsection{Purge Air Relief Valve Test}

1) Verify/close the bleed valve. Connect the outlet hose of a second PASS compressor to the outlet of the bleed valve. Setup this second compressor to operate in the "continuous run" mode by closing its hand valve (HV-l).

2) Startup the first PASS compressor and verify that the pressure on the test gage stabilizes at 75 to 80 psig.

3) Startup the second PASS compressor and verify that its receiver tank pressure is greater than 90 psig.

NOTE: In the following step the relief valve feature of the regulator unit at the end of the hose should open and begin to vent off excess pressure.

4) Slowly crack open the bleed valve, allowing the higher pressure from the second PASS to enter at the downstream side of the regulator unit, while observing the pressure on the test gage. The relief feature of the regulator unit should open and begin to vent before the pressure on the test gage exceeds $85 \mathrm{psig.} \mathrm{Record} \mathrm{the}$ pressure observed on the test gage in the appropriate space of the data sheet.

5) Shutoff both PASS compressor units and allow a 11 pressures to decay to ambient.

6) Remove the bleed valve, the pressure gage, and the tee fitting from the end of the hose. Secure the second PASS compressor until it is required for further testing.

Above section completed: 


\subsection{FLOW TEST}

This section of the procedure determines the capability for each PASS compressor unit to deliver the required amount of air flow at the end of its supply hose. Section 10.4 must be completed before performing this section.

1) Install a flowmeter to the outlet of the regulator unit located at the free end of the hose. Close test hand valve (TV-2) and open test hand vaive (TV-1).

2) Open hand valve (HV-1) to place the compressor unit in the "start/stop" mode of operation.

3) Turn the air compressor motor on. Air flow should be detected at the flow meter.

4) Slowly adjust the test hand valve (TV-1) until gage (PI-1) stabilizes near the minimum setting of the pressure switch (ref section 10.2, step 5). Read the air flow rate on the flowmeter, the receiver tank pressure gage (PI-1) and the regulator outlet pressure $(P I-3)$. Record flow and pressure readings in the appropriate block in the data sheet. Flow should not be less than 3.5 SCFM, regulator outlet pressure should remain between 75 to 80 psig.

5) Shut off the air compressor motor and allow the air receiver pressure to bleed down to zero.

6) Close hand valve (HV-2) and remove the flowmeter from the end of the hose.

Above section completed: 
WHC-SD-WM-TC-071

Revision 1

\subsection{CHECK VALVE TEST}

This section of the procedure performs a reverse flow leakage test on check valves $(\mathrm{CV}-2)$ and $(\mathrm{CV}-3)$ located in the air supply hose.

1) Verify/turn off the compressor and vent all pressure to ambient, as indicated on gage PV-1, by opening hand valve (HV-2) and opening the test hand valve at the end of the air supply hose.

2) Remove check valves (CV-2) and (CV-3) and leak check each one as follows:

a) Attach a suitable regulated air supply to the outlet side of the check valve.

b) Apply a piece of tape over the inlet side of the check valve and puncture a small hole in the tape.

c) Using a regulated air supply, apply a pressure of 5 to 10 psig to the outlet of the check valve. After waiting for at least one minute, check for leakage at the inlet of the check valve using soap solution. Record observations of any visible leakage in the appropriate block of the data sheet.

3) Remove the tape, and air supply from the check valves and reinstall them in the air supply hose. The flow direction arrow on the check valves must point away from the compressors.

Above section completed:

$$
\text { (signature of CTE) }
$$


WHC-SD-WM-TC-071

Revision 1

\subsection{HEAT STRIP THERMOSTAT TEST}

This section of the procedure verifies proper operation of the heat strip and its thermostat for each PASS compressor unit.

1) Verify/plug-in the power cord of the compressor unit heat strip to an appropriate electrical outlet.

2) After waiting at least five minutes for temperature stabilization, verify that heat strip indicator light (on the door of the compressor NEMA-4 panel) is not on.

3) Fill ice pack with ice and apply directly to the thermostat of the heat strip. Allow temperature of thermostat to stabilize. The indicator iight should illuminate indicating that the heat strip is energized. Indicate whether or not heat strip came on in the appropriate block of the data sheet.

4) Remove the ice pack and unplug the power cord of the heat strip.

Above section completed:

(signature of CTE)

(date) 
WHC-SD-WM-TC-071

Revision 1

\subsection{DUAL OPERATION TEST}

This section of the procedure provides assurance that the two PASS compressor units will function as intended when their outlets are connected together to a common hose.

1) Attach both compressor units to the purge supply hose. Install the flow meter at the outlet end of the hose and tether the hose to a rigid structure. Close the test hand valves (TV-1) and (TV-2) on the flowmeter.

2) Set one compressor unit to be in the "continuous run" mode by closing its hand valve (HV-1). Set the other compressor to be in the "start/stop" mode by opening its hand valve (HV-1). Close hand valve (HV-2) on both compressor units.

3) Turn both compressor units on and allow pressures to stabilize as indicated on gage (PI-1) of each compressor.

4) Slowly, open hand valve (HV-2) on the unit set up for continuous running, then slowly open hand valve (HV-2) on the unit set up for start/stop running. observe that regulator outlet pressure stabilizes at 75 to 80 psig on gage (PI-3).

5) Crack the test hand valve (TV-1) on the flowmeter to obtain a stable flow of approximately 3.5 SCFM. Observe both compressor units for normal operation over a period of approximately 20 minutes.

Note 1: The compressor set up for continuous running shouid run continuously with its unloader valve cycling to maintain pressure in its receiver tank between 100 to 135 psig as read on its gage (PI-1).

NOTE 2: The compressor set up for start/stop operation should cycle off and on only as necessary to make up for bleed air from its membrane dryer. The pressure switch of this unit should maintain pressure in its receiver tank between 85 to $120 \mathrm{psig}$ as read on its gage (PI-1).

NOTE 3: The regulator ( $P C-1)$ should maintain the hose outlet pressure between 75 to $80 \mathrm{psig}$ as read on gage (PI-3).

6) Close hand valve (HV-2) on the compressor unit which is running in the continuous mode. Observe the flow meter. The compressor unit which was setup in the start/stop mode should begin to cycle and continue to provide flow to the flow meter without interruption.

7) Slowly re-open hand valve (HV-2) on the compressor unit which is running in the continuous mode. 


\section{WHC-SD-WM-TC-071}

\section{Revision 1}

8) Swap the roles between the two compressors by closing hand valve (HV-1) on the unit which was running start/stop to make it now operate continuously, and open the hand valve (HV-1) on the unit which was running continuously to make it now run start/stop. Repeat steps 5, 6, and 7 .

9) Shut off both air compressor motors and allow the receiver tank pressure to bleed to ambient.

10) Close hand valve (HV-2) on both units and remove the flowmeter at end of hose.

Above section completed: 
WHC-SD-WM-TC-071

Revision 1

\subsection{POST-TEST OPERATIONS}

After all testing has been completed, both compressor units of the PASS shall be prepared for storage in accordance with this section of the procedure.

1) Turn off all power to the PASS. Unplug the extension cord from the wall outlet.

2) Open hand valve (HV-2). Verify that there is no pressure on gage (PV-1) then close hand valve (HV-2).

3) Re-install the quick connect to the end of the hose.

4) Open the drain valves on the bottom of the receiver and on the bottom of the prefilter, drain all water, then close drain valves.

5) Detach the power cord and the air hose from the PASS, coil them up, and place them over the handle bar of the unit.

6) Deliver the PASS to the appropriate storage area designated by the CTE.

\subsection{DISPOSITION OF TEST ITEMS}

Upon completion of testing the PASS will be used to support Cold Test of the LDUA in the FMEF.

\subsection{DATA SHEETS}

The data sheet, in which the CTE is to enter the test data required by the procedure (ref. section 10.0), is provided on the following page. A separate data sheet will be used for each PASS compressor unit. 
WHC-SD-WM-TC-071

Revision 1

DATA SHEET

CG\&A TESTING OF LDUA PURGE AIR SUPPLY SYSTEM (PASS)

Part Number H-6-14099-1

Comp. Unit Serial Number

\begin{tabular}{|c|c|c|c|c|c|}
\hline Step No. & Value & Units & $\begin{array}{l}\text { Name of person } \\
\text { entering data }\end{array}$ & Date & $\begin{array}{c}\text { Requirements/ } \\
\text { Comments } \\
\end{array}$ \\
\hline 10.1 .2 & & psig & & & $\begin{array}{l}\text { s/b } 140 \text { to } 144 \\
\text { psig }\end{array}$ \\
\hline $\begin{array}{l}10.2 .7 \\
\text { stops } \\
\text { run } \# 1 \\
\text { run } \# 2 \\
\text { run } \# 3\end{array}$ & TG PI-1 & $\begin{array}{l}\text { psig } \\
\text { psig } \\
\text { psig }\end{array}$ & & & s/b 120 psig max \\
\hline $\begin{array}{l}10.2 .7 \\
\text { starts } \\
\text { run } \# 1 \\
\text { run } \# 2 \\
\text { run } \# 3\end{array}$ & $\underline{T G} \underline{P I-1}$ & $\begin{array}{l}\text { psig } \\
\text { psig } \\
\text { psig }\end{array}$ & & & $\begin{array}{l}\text { s/b } 85 \text { to } 90 \\
\text { psig }\end{array}$ \\
\hline $\begin{array}{l}10.3 .7 \\
\text { unioads } \\
\text { run \#1 } \\
\text { run } \# 2 \\
\text { run } \# 3\end{array}$ & $\underline{\mathrm{TG}} \quad \underline{\mathrm{PI}-1}$ & $\begin{array}{l}\text { psig } \\
\text { psig } \\
\text { psig }\end{array}$ & & & $\begin{array}{l}\text { s/b } 10 \text { to } 15 \\
\text { psig above press } \\
\text { switch setting }\end{array}$ \\
\hline $\begin{array}{l}10.3 .7 \\
\text { loads } \\
\text { run } \# 1 \\
\text { run } \# 2 \\
\text { run } \# 3\end{array}$ & $\mathrm{TG} \quad \mathrm{PI}-1$ & $\begin{array}{l}\text { psig } \\
\text { psig } \\
\text { psig }\end{array}$ & & & $\begin{array}{l}\text { s/b } 100 \text { to } 105 \\
\text { psig }\end{array}$ \\
\hline 10.4 .1 .3 & $T G \quad P I-3$ & psig & & & $\begin{array}{l}\text { s/b } 75 \text { to } 80 \\
\text { psig }\end{array}$ \\
\hline 10.4 .2 .4 & & psig & & & $\begin{array}{l}\text { s/b } 85 \text { psig max } \\
\text { (crack pressure) }\end{array}$ \\
\hline 10.5 .4 & & $\begin{array}{l}\text { psig } \\
\text { SCFM }\end{array}$ & & & $\begin{array}{l}\mathrm{s} / \mathrm{b} 3.5 \mathrm{SCFM} \min \\
\text { at } 75 \text { to } 80 \mathrm{psig}\end{array}$ \\
\hline $\begin{array}{l}10.6 .2 . \mathrm{C} \\
(\mathrm{CV}-2) \\
(\mathrm{CV}-3)\end{array}$ & $N / A$ & $N / A$ & & & observation: \\
\hline 10.7 .3 & & yes/no & & & $\begin{array}{l}\text { heat strip } \\
\text { should come on }\end{array}$ \\
\hline
\end{tabular}


WHC-SD-WM-TC-071

Revision 1

\section{FIGURES}


WHC-SD-WM-TC-071

Revision 1

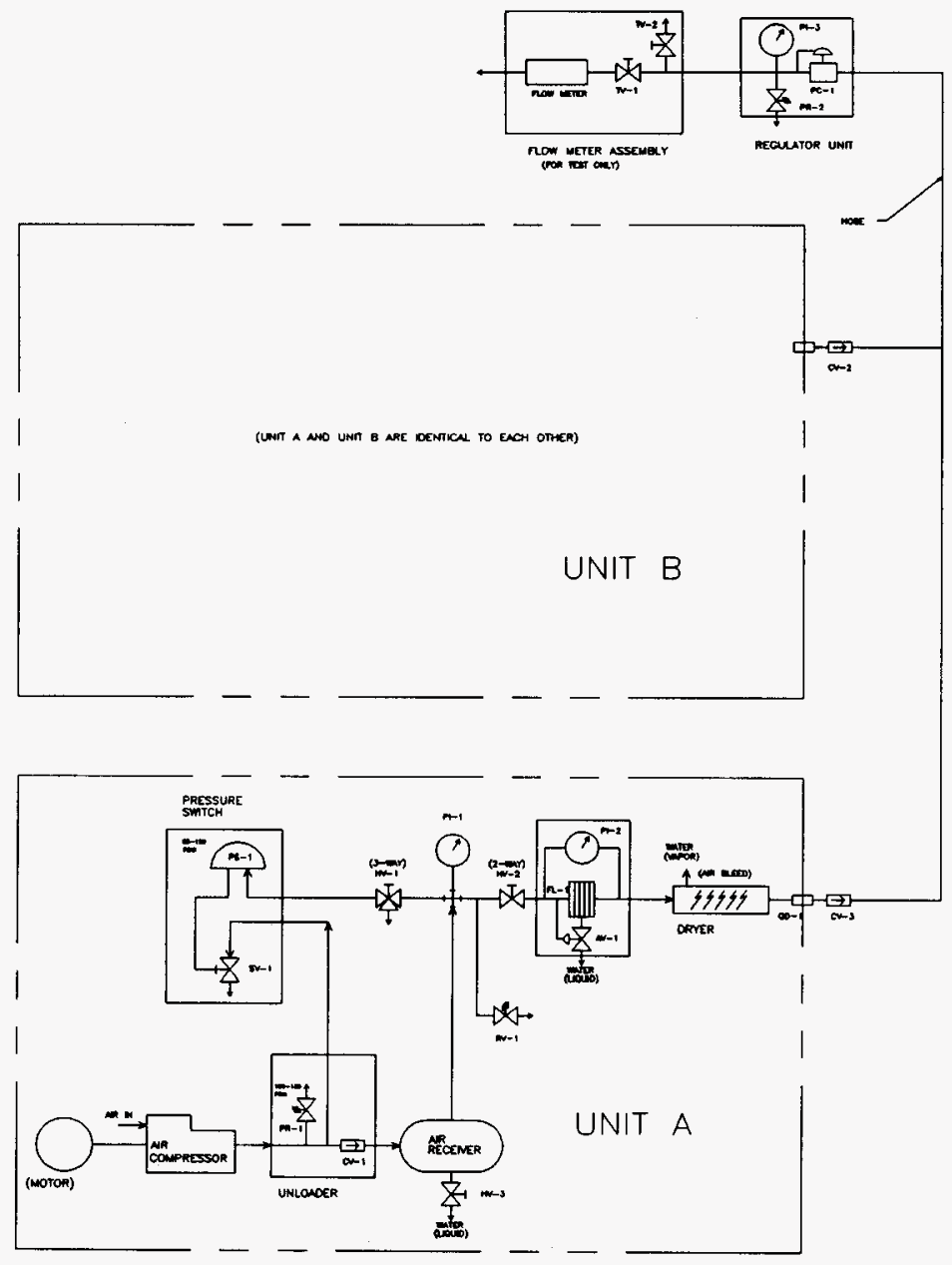

Figure 1

Mechanical Schematic. 
WHC-SD-WM-TC-071

Revision 1

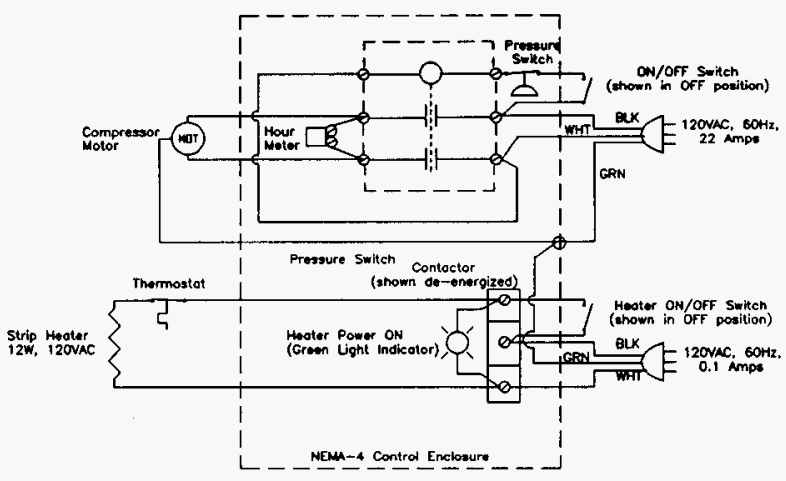

LDUA Purge Compressor Schematic

Figure 2

Electrical Schematic 